\title{
Multilocus enzyme electrophoresis - Application to the study of meningococcal meningitis and listeriosis
}

FE ASHTON, PHD

A MAJOR THRUST OF THE LABORATORY CENTRE FOR Disease Control (LCDC) is the investigation and delineation of infectious disease outbreaks through epidemiological and microbiological processes.

An important element of epidemiological investigations of disease outbreaks is the microbiological and genetic characterization of the causative microorganisms. For many years epidemiological investigations have been supported by laboratory methods which measure phenotypic variabilities in infectious agents. However, the discriminatory power of methods such as serogrouping, serotyping, bacteriocin typing, bacteriophage typing and antimicrobial susceptibility patterns are limited, since the phenotypic characteristics of microorganisms can be quite unstable.

New methodologies based on the detection of markers controlled by stable genetic material have become a major tool for determining clonality among a group of bacterial strains and therefore a

Correspondence and reprints: Dr FE Ashton. National Laboratory for Bacteriology, Bureau of Microbiology. Laboratory Centre for Disease Control, Ottawa, Ontario K1A OL2 major factor in more sophisticated epidemiological investigations. Some of the methods now used to characterize outbreaks include plasmid analysis, chromosomal fingerprinting by restriction fragment length polymorphism, polymerase chain reaction, RNA sequencing and multilocus enzyme electrophoresis (MEE).

MEE is based upon the principle that mutations in genes encoding for bacterial metabolic enzymes can be detected by differences in electrophoretic migration patterns of the enzymes (1). Since many bacterial enzymes are polymorphic, MEE provides a highly discriminatory method for detection of bacterial clones, which are identified by distinctive electrophoretic enzyme profiles termed 'electrophoretic types'. Fundamentally important is the fact that all strains exhibit an enzyme electrophoretic profile. Details on the methodology of MEE and its application to the study of clonal diversity and genetic structures for many bacterial pathogens have been published (1-3).

Several important features concerning the genetic relationships of meningococci and the spread of meningococcal disease have been revealed through major studies which have ex- 
ploited the discriminatory power of MEE (4-10). With the exception of serogroup A strains, the genetic structure of Neisseria meningitidis populations is quite heterogeneous, evidenced by the fact that 331 distinctive genotypes have been identified among 650 isolates belonging to eight serogroups $(4,5)$. This heterogeneity also permits differentiation among strains of different serosubtypes and electrophoretic patterns of outer membrane proteins within serogroups $(5,6)$. Thus, MEE has been used to monitor the intercontinental spread of group B disease due to a very closely related set of clones designated the 'ET- 5 complex' (7).

For $N$ meningitidis serogroup A, MEE has been used, in conjunction with outer membrane protein profiles, to divide 423 strains into four major families composed of 21 clones $(8,9)$. Subsequently, MEE was used to detect the intercontinental spread of group A disease due to a clone (designated III-1) which caused outbreaks in Nepal, Saudi Arabia and Chad (10). A combination of epidemiological investigations and MEE indicated that clone III-1, which previously had not been found in sub-Saharan Africa before 1983, was transmitted from south Asia to the Middle East by Muslims making their pilgrimage to Mecca, Saudi Arabia in 1987 (10).

A further example of the usefulness of MEE is illustrated by recent studies on the characterization of group $\mathrm{C}$ meningococcal disease isolates associated with an increase in group $\mathrm{C}$ disease during the past two years in Canada. In cooperation with provincial laboratories, studies at the LCDC have defined a series of 23 electrophoretic types among 233 group C serotype $2 \mathrm{a}$ strains. One electrophoretic type has accounted for $45 \%$ of all strains (unpublished data). The same clone was the cause of a focal outbreak in Ontario in January 1989 (11), and was associated with the spread of disease throughout most of the province during that year. This clone appears to be unique from most other clones causing group $C$ disease in that it exhibits for fumerase an electrophoretic variant which is rarely found in meningococcal strains from other countries (6). The unique property of this clone will permit further monitoring of its spread to other geographic areas.

A second important disease for which MEE has provided useful information is listeriosis. Many different electrophoretic types have been detected for Listeria monocytogenes with serotype 1/2a strains being more heterogeneous than strains of serotypes $1 / 2 b$ and $4 b(12-14)$. The existence of different electrophoretic types among different serotypes permits the use of MEE for determining the source of an outbreak and for identifying specific clones which may be associated with outbreaks of listeriosis.

Since 1987, the LCDC and the Food and Field Operations Directorates of the Department of National Health and Welfare, in cooperation with provincial laboratories, have been involved in a surveillance program for $L$ monocytogenes, with the aim of determining the public health importance of food contaminated with this organism. At the LCDC, MEE analysis of 48 serotype $4 \mathrm{~b}$ strains of $L$ monocytogenes isolated from humans with sporadic cases of listeriosis has revealed the existence of 14 electrophoretic types (unpublished data). One electrophoretic type also accounted for 27 of 29 strains isolated during the outbreak of listeriosis in Halifax. In addition, the strain isolated from coleslaw, which was implicated in the outbreak, proved to be the same electrophoretic type, thus lending support to the hypothesis that the coleslaw was the source of infection. The particular clone causing the outbreak in the Maritime provinces is very closely related to the clone(s) causing foodborne outbreaks in other parts of the world (12-14).

Because of its discriminatory power, MEE provides a valuable means for determining a potential link between contaminated food and a patient who consumed the product (15-17). Equally important are findings in this and other laboratories that patient and food isolates were of different electrophoretic types, thus allowing the dissociation of the consumption of a contaminated food with the disease $(13,14)$.

The LCDC is continuing to develop national databases on electrophoretic profiles of these and other important bacterial pathogens, and welcomes collaborative studies with other laboratories in order to achieve this aim. Such information is important for the delineation of the epidemiology and pathogenesis of various bacterial diseases.

\section{REFERENCES}

1. Selander RK, Caugant DA, Ochman H, Musser JM, Gilmour MN, Whittam TS. Methods of multilocus enzyme electrophoresis for bacterial population genetics and systematics. Appl Environ Microbiol 1986;51:873-84.

2. Selander RK, Caugant DA, Ochman H, Musser JM, Gilmour MN, Whittam TS. Population genetics of pathogenic bacteria. Microbiol Pathogen 1987;3:1-7.

3. Selander RK, Musser JM. Population genetics of bacterial pathogenesis. In: Iglewski BH, Clark YL, eds. Molecular Basis of Bacterial Pathogenesis. New York: Academic Press Inc, 1990:11-36.

4. Caugant DA, Bovre K, Gusted P, et al. Multilocus genotypes determined by enzyme electrophoresis of 
Neisseria meningitidis isolated from patients with systemic disease and from healthy carriers. J Gen Microbiol 1986;132:641-52.

5. Caugant DA, Mocca LF, Frasch CE, Froholm LO, Zollinger WD, Selander RK. Genetic structure of Neisseria meningitidis populations in relation to serogroup, serotype, and outer membrane protein pattern. J Bacteriol 1987; 169:2781-92.

6. Caugant DA, Zollinger WD, Mocca LF, et al. Genetic relationships and clonal population structure of serotype 2 strains of Neisseria meningitidis. Infect Immun 1987;55:1503-12.

7. Caugant DA, Froholm LO, Bovre K, et al. Intercontinental spread of a genetically distinctive complex of clones of Neisseria meningitidis causing epidemic disease. Proc Natl Acad Sci USA 1986;83:4927-31

8. Achtman M, Crowe BA, Olyhoek A, Strittmatter W, Morelli G. Recent results on epidemic meningococcal meningitis. J Med Microbiol 1988; 16:91-7.

9. Olyhoek T, Crowe BA, Achtman M. Clonal population structure of Neisseria meningitidis serogroup A isolated from epidemics and pandemics between 1915 and 1983. Rev Infect Dis 1987;9:665-91.

10. Moore PS, Schwartz B, Reeves MW, Gellin BG, Broome CV. Intercontinental spread of an epidemic group A Neisseria meningitidis strain. Lancet 1989;ii:260-3.
11. Ashton FE, Ryan JA, LeSaux N, et al. Isoenzyme typing of Neisseria meningitidis serogroup C. Can Dis Weekly Rep 1989;15:231-2.

12. Piffaretti JC, Kressebuch H, Aeschbacher M, et al. Genetic characterization of clones of the bacterium Listeria monocytogenes causing epidemic disease. Proc Natl Acad Sci USA 1989;86:3818-22.

13. Bibb WF, Gellin BG, Weaver R, et al. Analysis of clinical and food-borne isolates of Listeria monocytogenes in the United States by multilocus enzyme electrophoresis and application of the method to epidemiologic investigations. Appl Environ Microbiol 1990;56:2133-41.

14. Bibb WF, Schwartz B, Gellin BG, Plikaytis BD, Weaver RE. Analysis of Listeria monocytogenes by multilocus enzyme electrophoresis and application of the method of epidemiologic investigations. Int $J$ Food Microbiol 1989;8:233-9.

15. Farber JM, Carter AO, Varughese PV, Ashton FE, Ewan EP. Listeriosis linked to the consumption of alfalfa tablets and soft cheese. N Engl J Med 1990;322:388.

16. Centers for Disease Control. Listeriosis associated with consumption of turkey franks. MMWR 1989;38:267-8.

17. Vogt RL, Donnelly C, Gellin B, Bibb B, Swaminathan B. Linking environmental and human strains of Listeria monocytogenes with isoenzyme and ribosomal RNA typing. Eur J Epidemiol 1990;6:229-30. 


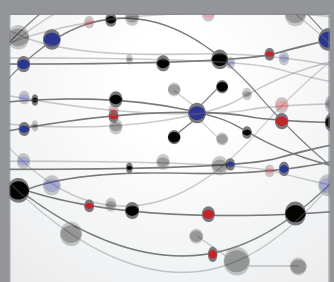

The Scientific World Journal
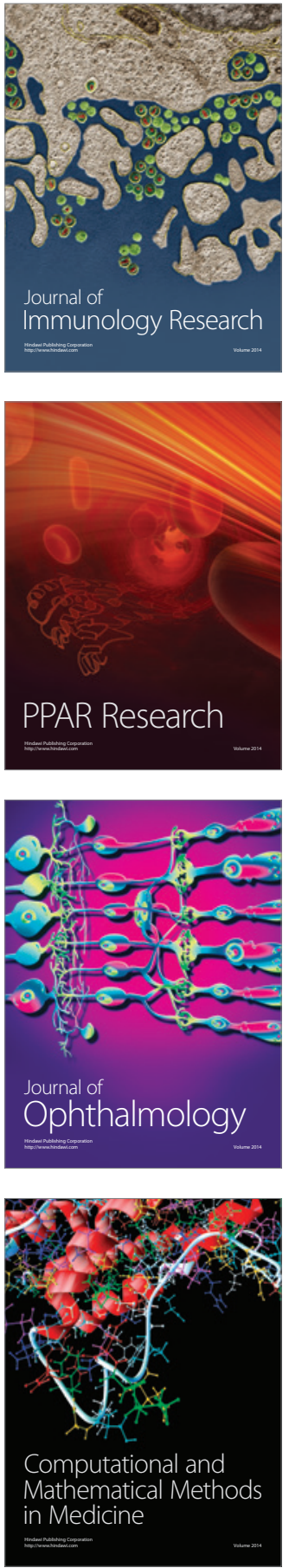

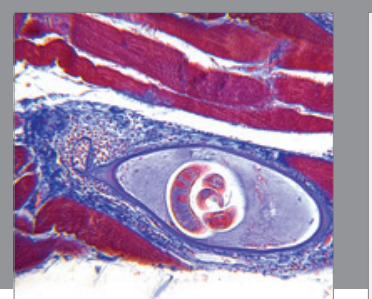

Gastroenterology Research and Practice

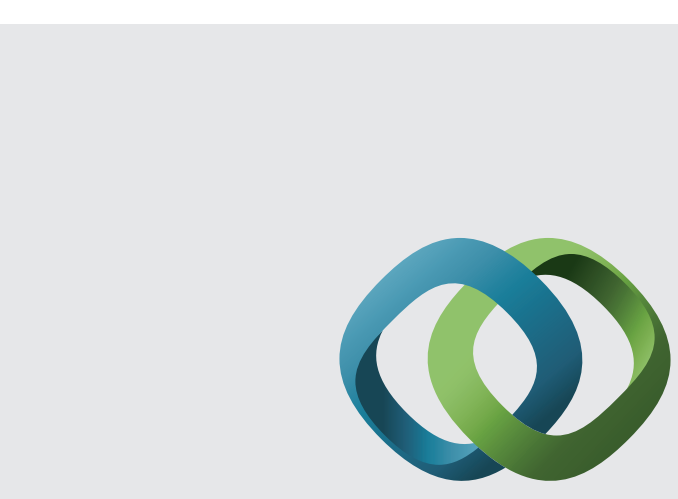

\section{Hindawi}

Submit your manuscripts at

http://www.hindawi.com
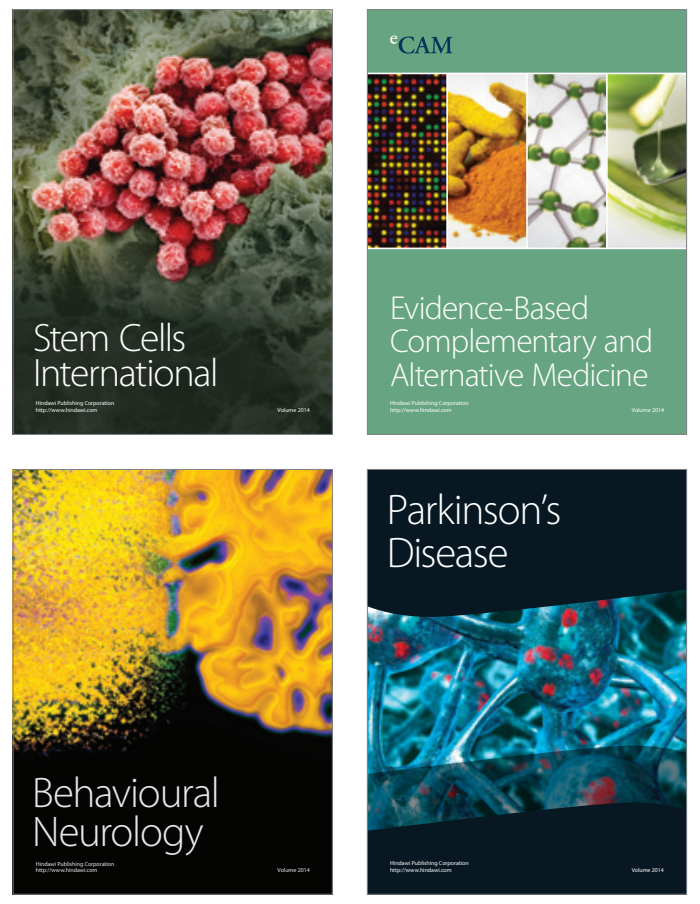
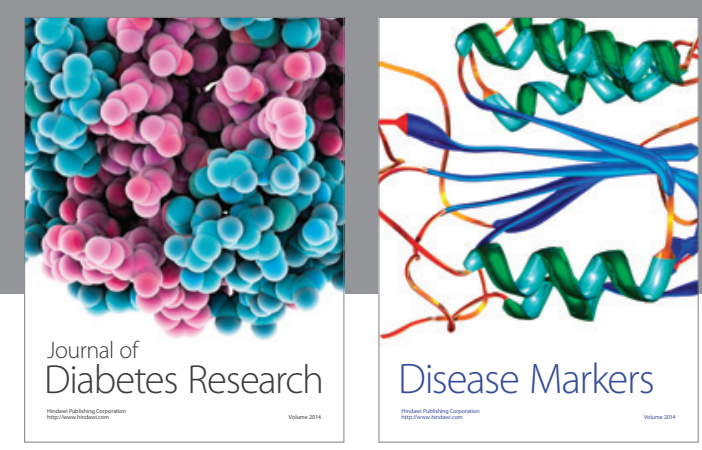

Disease Markers
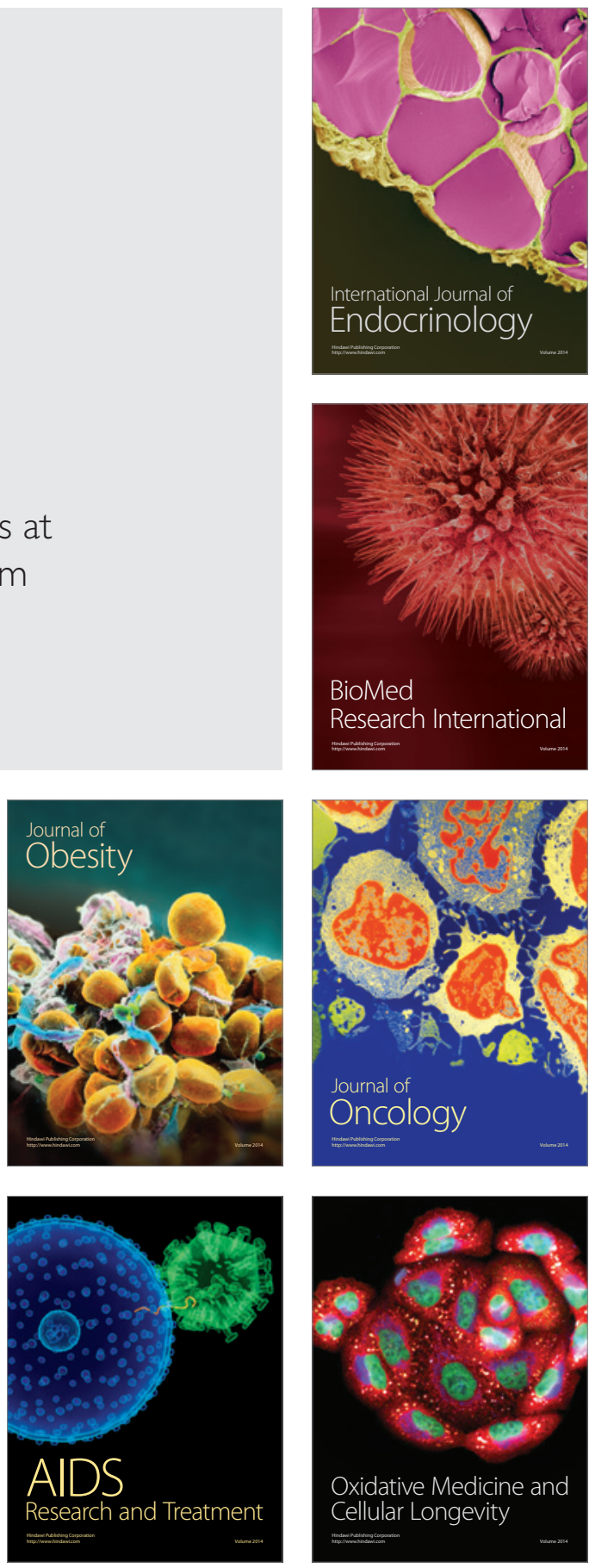